Corresponding author:

Affiliation:

Postal address:
Aspa Baroutsis

Queensland University of Technology

Queensland University of Technology

Faculty of Education

GPO Box 2434

Brisbane QLD 4001

Australia

Bio:

Aspa Baroutsis is a researcher at the Faculty of Education at the Queensland University of Technology. Aspa's research is focused on media, policy, and public constructs of schools, teachers and students, underpinned by understandings of social justice and 'voice'. Her current research explores the media construction of school performance in the Programme for International Student Assessment (PISA) results in Australia. Aspa's two most recent publications are in the British Educational Research Journal and the Journal of Education Policy.

Author:

Bob Lingard

Affiliation:

The University of Queensland

Postal address:

The University of Queensland

School of Education

Brisbane QLD 4072

Australia

Bio:

Professor Bob Lingard works in the School of Education at The University of Queensland, where he researches and teaches in the sociology of education and policy sociology in education. More specifically, he has been researching globalization and the education work of the OECD since the mid-1990s and published widely on the topic. His recent books included the co-authored, Globalizing educational accountabilities (Routledge, 2016), the co- edited, National testing in schools (Routledge, 2016), and the co-edited, The Handbook of Global Education Policy (Wiley-Blackwell, 2016). 


\title{
Counting and comparing school performance: An analysis of media coverage of PISA in Australia, 2000-2014
}

\author{
Abstract \\ This paper empirically documents media portrayals of Australia's performance on the \\ Program for the International Student Assessment (PISA), 2000-2014. We analyse \\ newspaper articles from two national and eight metropolitan newspapers. This analysis \\ demonstrates increased media coverage of PISA over the period in question. Our \\ research data were analysed using 'framing theory' (Entman, 1993), documenting how \\ the media frames stories about Australia's performance on PISA. Three frames were \\ identified: counts and comparisons; criticisms; and contexts. Most of the media \\ coverage (41\%) was concerned with the first frame, counts and comparisons, which \\ analysed PISA data to provide 'evidence' that was then used to comparatively position \\ Australia against other countries, reference societies, which do better, with particular \\ emphasis on Finland and also Shanghai after the 2009 PISA. The other two frames \\ dealt with criticisms and contextual issues. This paper only focuses on the first frame. \\ The analysis demonstrates the ways in which media coverage of Australia's PISA \\ performance has had policy impact.
}

Keywords: PISA, media, newspaper analysis, policy, school performance

\section{Introduction}

In this paper we provide documentation and analysis of media coverage in Australia of the OECD's Program for the International Student Assessment (PISA) for the period 2000-2014. PISA is an international sample-based test of reading, mathematical and scientific literacies for 15 year olds that purports to measure their capacities to apply their literacy, mathematics and science knowledges in 'real world situations'. The PISA tests are not based in national curricula, but implicitly at least assume a curricula isomorphism between schooling systems (Sellar \& Lingard, 2015). PISA was first administered in 2000 and every three years subsequently. The test was created because of pressure from OECD member nations in the 
late 1990 s, particularly the US, for such a test of the comparative performance of national schooling systems to be used as a surrogate measure of a given nation's future economic competitiveness. The latter became a concern with the globalization of national economies and a human capital rearticulation of education policy, arguing that the best economic policy a nation could pursue was to focus on producing large amounts of high quality human capital. The OECD throughout the 1990s was significant in proselytizing such human capital purposes of schooling as a global education policy discourse and PISA scores were taken to be surrogate or proxy measures of the quality of nations' human capital (Henry, Lingard, Rizvi, \& Taylor, 2001; Auld \& Morris, 2016). In the time since its inception, PISA has become more influential in policy terms in both global governance of education and in national policy-making with more nations participating over time (Sellar \& Lingard, 2014).

The OECD structures the reporting of nations' performance on this international large-scale assessment in terms of quality. Quality refers to a nation's mean scores on PISA. The OECD also administers a survey to all participating students, which is used to determine their socio-economic background. The OECD represents nations' comparative performance against quality and equity, which is measured by the strength of the correlation between socio-economic background and performance. Top performing nations are seen to be both high quality and highly equitable. Australia is often identified as a country with high quality and medium equity.

The OECD releases two reports analysing the performance of each participating country. The first report, released in December of the following year, is a summary of national and international comparative performance data and is the report that receives the greatest media attention. This media attention on PISA, which we document below, also has policy effects with the emphasis being much more on quality of performance (mean national score) than on equity (Wiseman, 2013). The secondary, more detailed analyses are made 
available two years after the test is administered, and provide much helpful data for policy, especially in our view in respect of equity matters. However, these receive much less media coverage with implications for policy take-up.

While our study is Australian in focus, it has relevance in the global policy context because of the strengthening global policy significance of PISA (Sellar \& Lingard, 2014) and enhanced salience of the media in policy (Lingard \& Rawolle, 2004; Baroutsis, 2016). As Blackmore and Thorpe (2003) state:

The media is critical in the (re)production of policy as discourse, in that it becomes both the medium and the message for what policy is read to mean. The media simultaneously creates and taps into educational discourses (popular, professional and academic) that take on particular dominant readings in specific contexts ... (p. 580)

Additionally, the increased emphasis and media attention foreground educational issues, thrusting these issues into public awareness (Figazzolo, 2009). The attention due to the enhanced media coverage also highlights the OECD media strategy for the dissemination of PISA results. Important here as well is the fact that the OECD makes all of the PISA performance data publicly available to all, including the media, think tanks and edubusinesses. Related, we note how governments are taking greater notice of comparative PISA performance for framing and developing policy, and that think tanks and edubusinesses are also using the publicly available PISA data to write their own analytical reports, which in turn receive much media coverage. It is also our argument that the media framing of Australia's PISA performance, with a focus on quality rather than equity, has significant policy effects in Australia.

The paper is structured in the following ways. Initially, we review the literature specifically on PISA and the media and the broader literature on media portrayals of education policy. Next, we outline our theoretical and methodological perspectives. We 
outline the data sources, namely 173 newspaper articles, for the period in question.

Subsequently, we explain our data and provide an analysis of it, set against the literature and cognate research. This is done in three sections: an overview of Australian media coverage of PISA; an outline of the dominant frames privileged in media coverage; and a more detailed analysis of one of these frames that focuses on counts and comparisons.

\section{PISA and the media}

While many scholars have written about PISA, we concur with Dixon et al. (2013) that a much smaller body of writing provides analyses of PISA by focusing on the media. In particular, when limiting our search to those works that were written in English, we draw on peer-reviewed articles and other reports that specifically use the print media as a data source and/or have undertaken a systematic analysis of media constructions of PISA testing and national performance. Consequently, we encourage further research in this area, as this potentially can provide counter-narratives to the public discourses available in the media.

Literature in this area tends to focus on media coverage within specific countries, as well as some cross-country comparisons of newspaper constructions of PISA performance. Countries that have been the subject of such analyses include Hungary (Bajomi, Berényi, Neumann, \& Vida, 2009); Portugal (Afonso \& Costa, 2009); Scotland (Grek, 2008; Grek, Lawn, \& Ozga, 2009); France (Mons \& Pons, 2009); and Romania (Rostas, Kosa, Bodo, Kiss, \& Fejes, 2009). These studies were completed as part of the Know\&Pol project (20062011) that investigated the reception of PISA in these countries. Other studies reviewed newspapers in Turkey (Gür, Çelik, \& Özoğlu, 2012); Norway (Elstad, 2012); the United States (Stack, 2007); Canada (Stack, 2006); Japan (Takayama, 2008, 2010); and Israel (Yemini \& Gordon, 2015). Additionally, some studies developed comparative accounts of PISA in the media. These included comparisons between Germany, Finland, France and 
Britain (Dixon et al., 2013); Norway, Sweden and Finland (Fladmoe, 2011); Germany and the US (Martens \& Niemann, 2013); Scotland, Portugal and France (Pons, 2011); Australia, Germany and South Korea (Takayama, Waldow, \& Sung, 2013; Waldow et al., 2014). Finally, a non-peer reviewed report by Education International, the international federation of unions representing teachers, produced a report analysing policy debates globally arising from the 2006 PISA (Figazzolo, 2009).

Many of these studies found that there was a propensity towards negative media coverage (Dixon et al., 2013; Elstad, 2012; Gür et al., 2012; Pons, 2011). Patterson (1996) suggests that the dominant model of news coverage is moving away from descriptive style to an interpretive style that gives the journalists greater control over the content (p. 97); and as a consequence, there is a focus on the negative elements of the news. Moreover, Örnebring and Jönsson (2004) suggest that the rise of tabloid journalism, as distinct from tabloid newspapers, that 'thrive on sensation and scandal' also focuses on negative media coverage (p. 283). Within these shifts, we see a tendency for the media coverage to be simplistic and often emphasising league tables and rankings (Figazzolo, 2009; Gür et al., 2012; Martens \& Niemann, 2013; Pons, 2011; Takayama, 2008). League tables, as a mode of comparison, are influential in the design of contemporary education policies within a neo-liberal framework of governance (Takayama, 2008). Mons and Pons (2009) suggest that this simplistic media coverage using league tables could be due to the journalists' lack of expertise in the area of statistics and statistical analysis. $\mathrm{Wu}(2010)$ argues that there is a large portion of the public, politicians and journalists, who 'misquote or misuse' the data from large-scale assessments (p. 15) or make 'claims and conclusions' that lack statistical rigour (p. 24). However, a more critical reading of this identifies such practices as 'mechanisms of public shaming and blaming' (Takayama, 2008, p. 388). At times, this has included 'false leaks' and 'erroneous information' (Mons \& Pons, 2009, p. 84) that privileged certain discourses about PISA 
results in particular countries and framed public understandings in particular ways. For example, discourses of 'crisis' were often associated with media constructions of PISA performance (Mons \& Pons, 2009; Stack, 2006, 2007; Takayama, 2008, 2010; Takayama et al., 2013; Waldow et al., 2014), creating a 'public outcry' over the performance of national education systems (Yemini \& Gordon, 2015).

Media coverage was found to peak in certain countries at times of perceived crisis. This coverage promoted a policy orientation towards reform that supports a decontextualised 'copy and paste' mentality, advocating for the substitution of the features of the wellperforming school systems of one country to other 'poorly performing' countries (Figazzolo, 2009). These perceived high-performing education systems (reference societies), such as Finland or Shanghai, become the 'symbol of educational excellence' (Takayama, 2008, p. 387); 'global models' of 'best practice' (Kamens, 2013, p. 2); and at times, the 'poster boy' for educational reform (Waldow et al., 2014, p. 2). However, such practices most often fail to give credence to the equity-related features of individual countries. Here, we see the importance of PISA testing in this practice of external policy referencing and the influence of local factors such as media construction of a country's PISA performance in choosing reference societies (Lingard, 2011; Sellar \& Lingard, 2013; Waldow et al., 2014). We note as well in terms of PISA policy effects that PISA results are most often utilised by national governments to justify reforms already underway; this is the process of 'externalisation' in policy production (Schriewer, 1990; Steiner-Khamsi, 2003; Steiner-Khamsi \& Waldow, 2012).

Discourses of crisis circulated when countries experienced gaps between their own perceptions of their education systems and their PISA results (Martens \& Niemann, 2013); and when slippage occurred in a country's world rankings on PISA results. First, in respect of the perception gap, countries including Germany and Japan experienced 'PISA shock' (Grek, 
2009; Takayama, 2010; Takayama et al., 2013; Waldow et al., 2014). Perhaps the best example of this was in Germany, when the empirical evidence did not align, that is, was significantly lower than the country's self-perceptions of the success and quality of their educational system (Martens \& Niemann, 2013). This was also well illustrated in the French example, where up until the PISA 2006 test, the French media expressed a 'weak interest' in PISA (Mons \& Pons, 2009), demonstrating policy reactions of 'indifference' (SteinerKhamsi, 2003). The French moved from ignoring the country's results or only covering them from a technical perspective to debates about the types of policy reforms that should be implemented (Mons \& Pons, 2009). Secondly, debate in the media intensified when a country experienced slippage in the global rankings of PISA results (Elstad, 2012; Martens \& Niemann, 2013). Globally, these scenarios were often scarifying in their representations in the media (Pons, 2011) and resulted in policy reactions of 'scandalisation' at the weaknesses of their country's educational system (Steiner-Khamsi, 2003). However, successful countries did not always escape media condemnation. Given that Finland is often a reference society for many other nations, it could be expected that the Finnish media cover the country's PISA performance using mechanisms of 'glorification' that focus on the strengths of their educational system (Steiner-Khamsi, 2003). However, this was not always the case. In their study, Martens and Niemann (2013) concluded that there was no correlation between a country's rank and the media reaction, that is, a poor ranking did not necessarily trigger extensive media debate regarding education systems and reform. Similarly, Dixon et al. (2013) found that Finland, perceived as a high-performing country, received the same percentage of negative reportage as Germany. Many of these findings are also identified in our research and will be discussed further in the following sections. 


\section{Methodological considerations}

This section of the paper identifies the methods we used to gather and analyse the research data. The paper draws on 173 newspaper articles from 10 Australian newspapers. The newspaper articles were gathered through the Factiva database. The parameters focused on 10 Australian newspapers across a 14-year period (2001-2014): two national and eight metropolitan, one from each state and territory. There are two main corporations that hold newspaper interests in Australia: News Corp Australia and Fairfax Media. As outlined in Table 1, the newspapers in this study represent a range of coverage and ownership with five of the newspapers owned by News Corp Australia; four by Fairfax Media; and one by Seven West Media.

Table 1: Outline of newspaper coverage and ownership

\begin{tabular}{|c|c|c|c|}
\hline \multirow[t]{2}{*}{ Coverage } & \multicolumn{3}{|c|}{ Ownership } \\
\hline & News Corp Australia & Fairfax Media & Seven West Media \\
\hline National & The Australian & Australian Financial Review & \\
\hline \multirow[t]{4}{*}{ Metropolitan } & $\begin{array}{l}\text { The Courier Mail } \\
\text { (Queensland) }\end{array}$ & $\begin{array}{l}\text { Sydney Morning Herald } \\
\text { (New South Wales) }\end{array}$ & $\begin{array}{l}\text { The West Australian } \\
\text { (Western Australia) }\end{array}$ \\
\hline & The Mercury (Tasmania) & The Age (Victoria) & \\
\hline & $\begin{array}{l}\text { The Advertiser (South } \\
\text { Australia) }\end{array}$ & $\begin{array}{l}\text { Canberra Times (Australian } \\
\text { Capital Territory) }\end{array}$ & \\
\hline & $\begin{array}{l}\text { Northern Territory News } \\
\text { (Northern Territory) }\end{array}$ & & \\
\hline
\end{tabular}

The database search, using 'PISA' as the search term, generated 462 articles, with only 37 per cent of these being identified as relevant to our study. The search included articles by journalists, editorials, op-ed pieces and features from opinion writers and commentators. A systematic two-pass system was used to identify texts that were not relevant to the study. The first-pass reading discarded 44 per cent of the articles. The second-pass reading discarded another 33 per cent of the articles, retaining 173 news reports, across 14 years, from the 10 Australian newspapers. Of these articles, 11 per cent were duplicate 
reports that were syndicated across newspapers or editions; these were retained in the total as they represented a level of coverage. These retained reports focused on schools and education systems, and were predominantly about PISA, that is, they did not simply make a passing reference to the program. The selected timeframe, 2000-2014, represents longitudinal data from the period of the first PISA assessment in Australia to consideration of media representations of the most recent PISA results.

Matthes (2009), in an extensive review of the media framing research, suggests that much of this lacks operational precision and is mainly descriptive in nature. In this paper, we have drawn on Entman's $(1993,2004)$ work on framing analysis in media studies. However, in acknowledgement of Matthes' point about lack of operational precision, we have also used thematic analysis (Braun \& Clarke, 2006) and qualitative content analysis (Macnamara, 2005). While we acknowledged the constructed nature of all categories such as themes, the thematic analysis became the initial tool that provided the flexibility that enabled the incorporation of other analytic methods in the study (Boyatzis, 1998). The frame analysis identified sub-groupings within the initial themes that provided elaborations through the identification of media constructions of Australia's PISA performance. A qualitative content analysis was used to identify the fames and enabled the collating and reporting of frames in the media texts. Additionally, the analysis enabled the use of simple descriptive statistics and tabulations based on counts of the data and the visual display of these data. Drawing on these data, three frames were identified in the analysis: those that focus on counts and comparisons, criticisms, and contexts. While the three frames are briefly described below, in this paper we only focus on counts and comparison, the most prevalent of the categories in the data.

\section{Australian media coverage of PISA}

Australia is said to have an oligopolistic media sector and thus potentially lacks diversity in 
both content and perspective (Cunningham, 2010). The concentration in media ownership across the three media conglomerates comprising our data set: News Corp Australia, Fairfax Media, and Seven West Media; two of which, News Corp Australia (49 per cent) and Fairfax Media (48 per cent), equally dominate the publications, providing the bulk of the coverage of Australia's performance in PISA. Additionally, News Corp Australia dominates the industry with 57 per cent of the daily newspaper circulation (Papandrea \& Tiffen, 2011).

While News Corp Australia has the slightly larger volume of articles in this data set, one of their newspapers, The Australian, dominates media coverage of Australia's performance on PISA with 37 per cent of reports (see Figure 1). This is nearly two and a half times greater than the next closest coverage, in the Sydney Morning Herald and The Age, both Fairfax Media newspapers, with 15 and 16 percent coverage respectively. From this perspective, given that The Australian has a national circulation, we can see that News Corp Australia is dominant in the coverage of PISA performance. Consequently, their representations are privileged, given the extent of coverage. Interestingly, the other News Corp Australia publications have very little coverage of PISA, with the Tasmanian newspaper having no articles on the topic. 
Figure 1: Aggregated percentage of PISA articles per newspaper 2001-2014 $(n=173)$

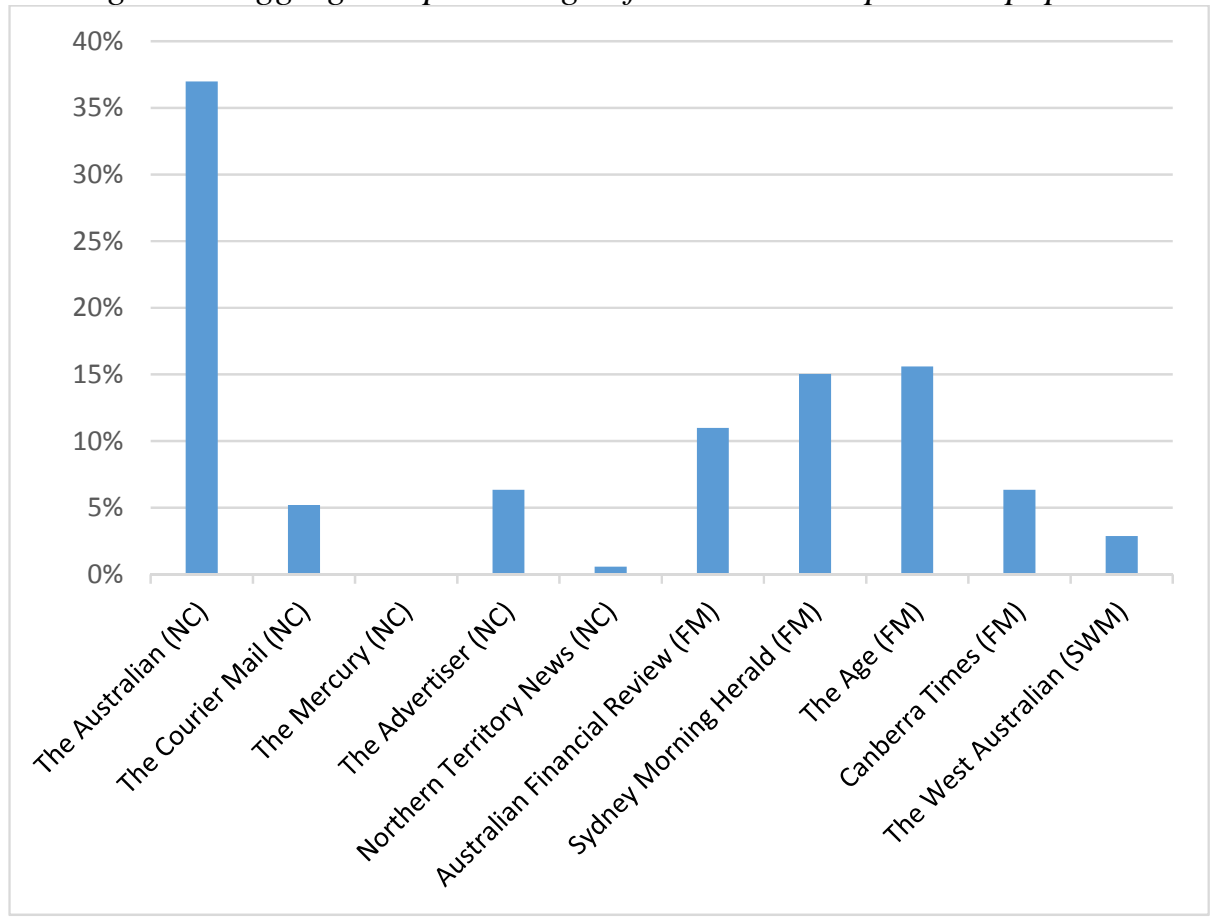

In a 2010 survey of Australian journalists, based on self-reporting, Josephi and Richards (2012) found that 50 per cent of Australian journalists' perspectives aligned with 'left of centre' politics, that is, in this context, with the policies of the Australian Labor Party and the Greens, rather than the Liberal or National parties; 28 per cent indicated a 'middle of the road' approach; while 14 per cent were 'right of centre' (p. 119). While it is often stated by the media themselves that they advocate for left-wing 'political liberalism', a claim that has often and strenuously been debunked (cf Alterman, 2003), there is a propensity towards a more conservative political agenda in the print media (McKnight, 2010). While News Corp Australia adopts a more conservative approach, Fairfax Media leans toward a more central 'liberal bias’ (McKnight, 2010, p. 310).

These media organisations, as policy actors, play a distinct role in shaping public realities (McCombs \& Shaw, 2007) and often play an active role in the selection of particular stories (Elstad, 2012). They are not independent actors in the field in that 'their ownership 
can have political or ideological affiliations' (Figazzolo, 2009, p. 22). Newspapers often undertake the 'conscious and systematic promotion' of particular agendas (Burgess, 2010, p. 60). In a recent survey, 15 per cent of Australian journalists self-reported that they saw their media role as 'setting political agendas' (Josephi \& Richards, 2012, p. 121). These practices seek to influence politics and policy (Birks, 2010). However, within this agenda-setting context, newspapers, editors, and journalists perceive their media role as that of policy reinforcement, rather than policy construction or contestation (Baroutsis, 2016).

The PISA reports are published the year after the test year, that is, in 2001, 2004, 2007, 2010, and 2013 (depicted by arrows in Figure 2). When reviewing the volume of reporting about Australia's PISA performance, aggregation based on annual figures, we see three trends emerging (see Figure 2). First, our data show that there is a steady increase in coverage of Australia's PISA performance over time. For example, while there were no newspaper reports specifically about PISA in 2000, 2001, and 2003, across all newspapers, the trend-line shows a steady overall increase in coverage in Australia. This can be said to parallel the increased significance of PISA at the OECD, globally and nationally.

Figure 2: Aggregated percentage of newspaper articles, by year 2000-2014 $(n=173)$

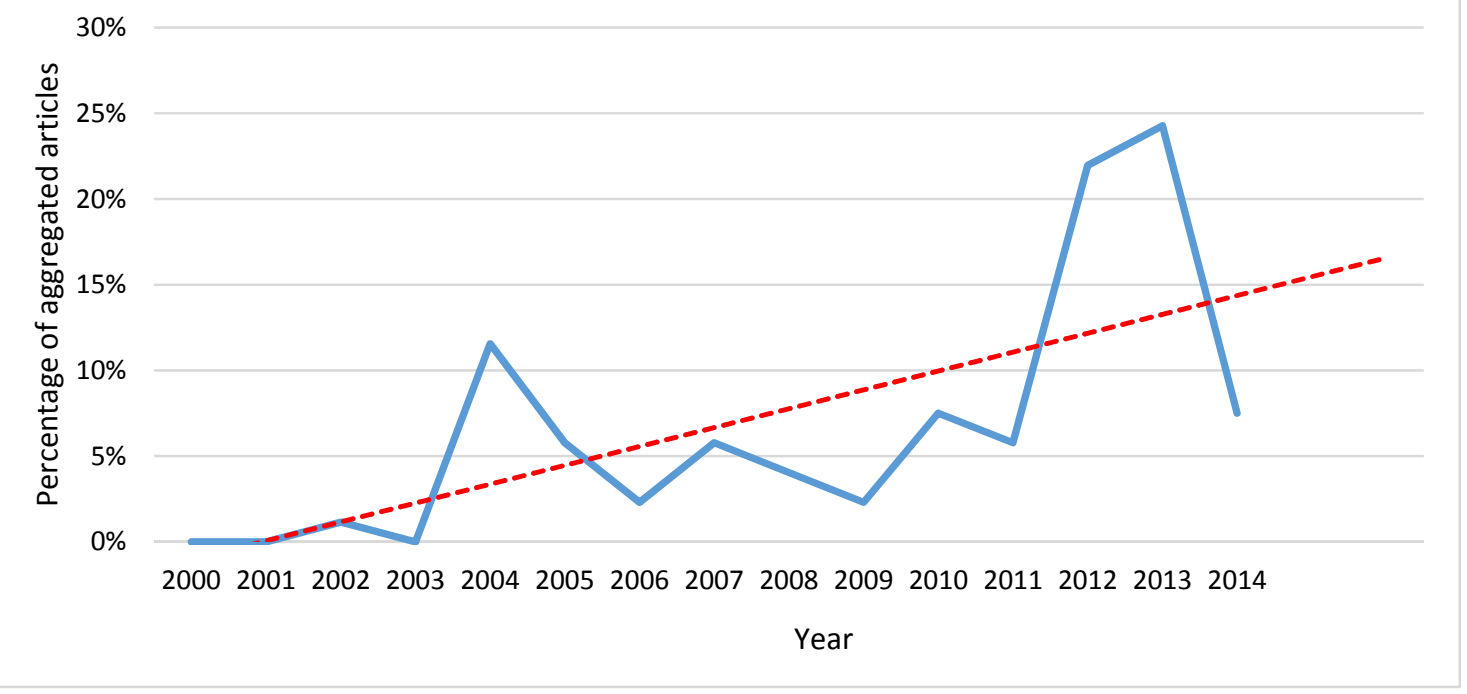


Secondly, not surprisingly, coverage peaks during a report year (see Figure 2 and Figure 3). While this was not the case in the Australian data in 2001, all other report years show an increase in coverage from either the previous year or the previous two years. For example, Figure 2 shows coverage in 2010 was 8 per cent of the total number of articles on PISA, an increase from the previous two years that accounted for only 4 per cent in 2008 and 2 percent in 2009.

Thirdly, there are two distinct reporting peaks; one in 2004 and another in 2012/2013. Australia first participated in PISA in 2000, and by 2004, the relevance of this testing regime was only just starting to be acknowledged by the media (see Figure 2 and Figure 3). Especially given that, in the 2000 and 2003 PISA years, Australia's produced good results, attaining competitive mean scores (see Figure 4), which prompted an increase in coverage of 12 percentage points in 2004, when compared with that in the previous year (see Figure 2). This prompted interest in PISA, with headlines such as: 'Australia's education system gets full marks' in The Canberra Times (O'Connor, 2004); 'How Australia can go to the top of the class' (The Australian, 2004); and 'Aussies score top marks in world test' (Buckingham, 2004), both in The Australian. While coverage during this period did outline Australia's success, this was done cautiously, with some of it highlighting issues of equity in relation to the poor results by Indigenous students and girls (see section on framing reportage below). When reviewing the disaggregated data, based on individual newspaper coverage, there appears to be a third peak during 2007 (see Figure 3). However, this is only reflected in one newspaper, while the other two peaks were across newspapers. 
Figure 3: Disaggregated number of Australian newspaper articles on PISA, by newspaper 2000-2014 $(n=173)$

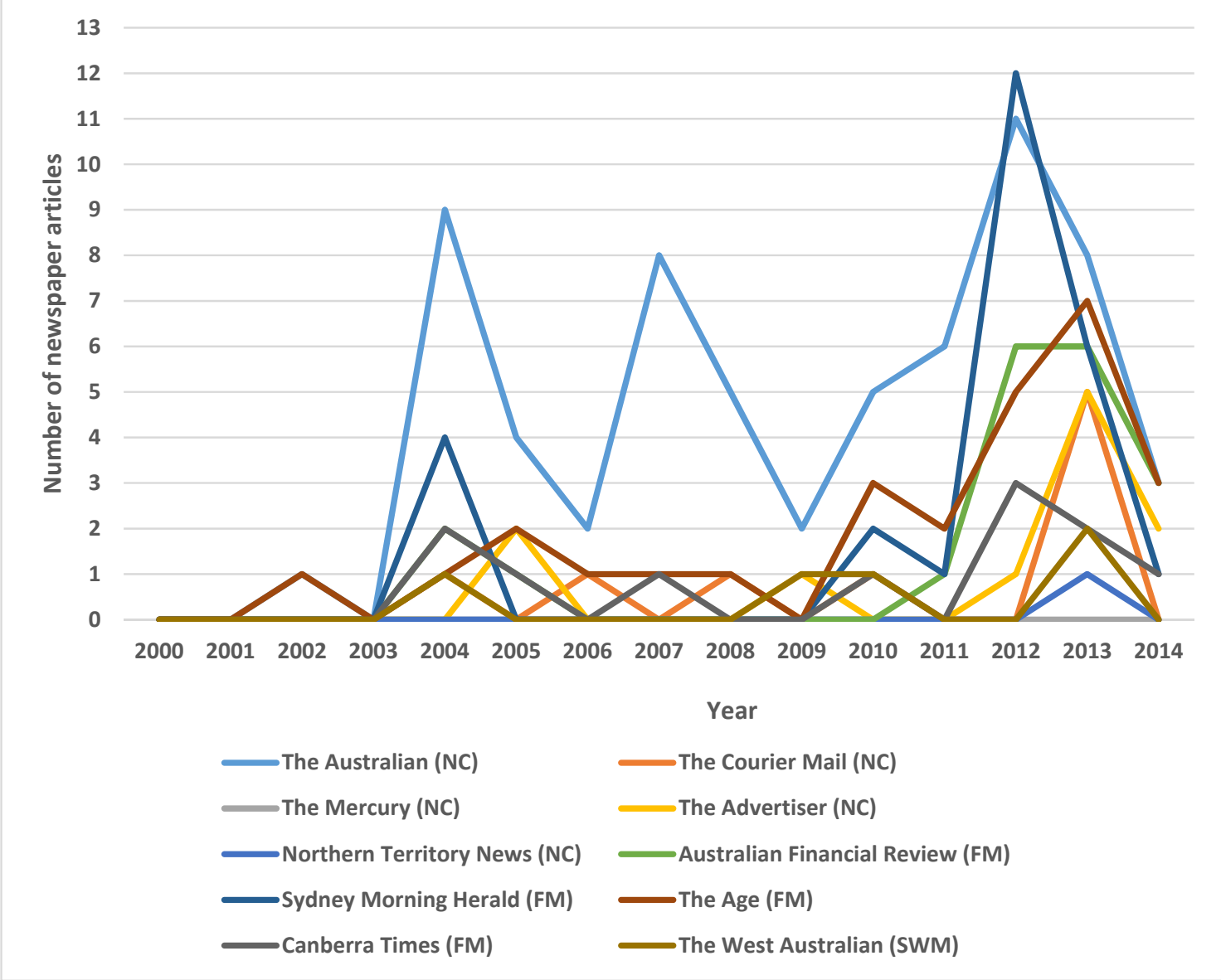

Figure 4: Australia’s PISA results as mean scores 2000-2012

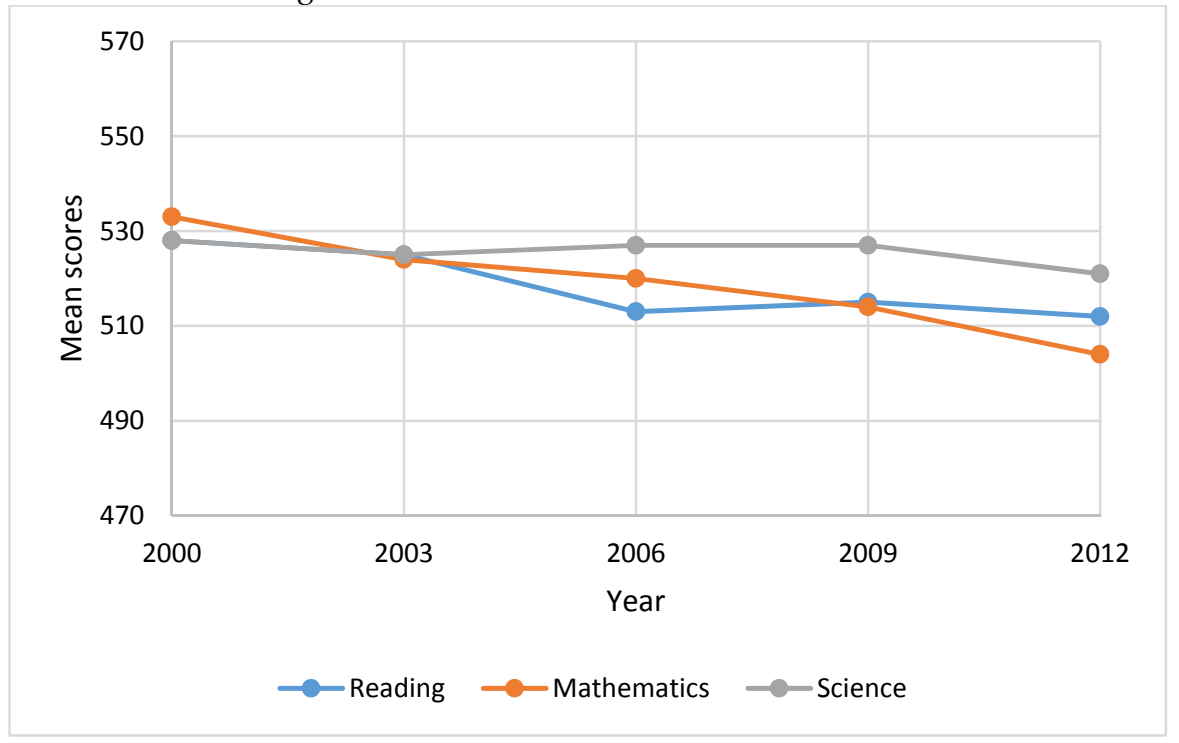


By 2012, Australia's PISA results had declined, for example, there was a 7-point drop in science and a 16-point drop in reading mean scores between 2000 and 2012, but more significantly, a 29-point drop in mathematical literacy (see Error! Reference source not found.Figure 4). This accounts for the second peak period of reporting with increases of 16 percentage points in coverage compared with that of the previous year. The second peak was across two years, starting in 2012, a PISA test year, but coverage was at its highest in 2013, a PISA report year. Media coverage in 2012 accounted for 22 per cent, while it was 24 per cent in 2013. This is a combined value of 46 per cent, just under half the total newspaper reports in the 14-year period (see Figure 2 and Error! Reference source not found.Figure 3). This could possibly be described as a media 'frenzy' about Australia's PISA performance. The timing of the spike, that is, in 2012 rather than 2013 which is the PISA report year, does perhaps represent an anomaly in our data. However, this could be a strategy that pre-empted Australia's declining performance, building tension (and consequently selling newspapers), given the media's propensity for the 'dramatic narrative' (Paletz \& Entman, 1981). In all, as was evident in other research, the slippage in a country's results, especially when a country's perceptions of their education system is contrary to their performance on PISA (Elstad, 2012; Martens \& Niemann, 2013; Mons \& Pons, 2009; Pons, 2011), and as discussed earlier, often leads to 'PISA shock'.

Australia experienced PISA shock in 2010 following Shanghai’s outstanding performance on PISA in the 2009 test (Sellar \& Lingard, 2013), with Shanghai students outperforming, by a considerable extent, even those in Finland. Interestingly, the shock was somewhat delayed in fully manifesting in the media, and resulted by and large from the media coverage of a report from an Australian think tank, The Grattan Institute, entitled, Catching Up: Learning from the best school systems in East Asia (Jensen, 2012). We note 
that think tank reports are written in a language and style to attract such media coverage (Medvetz, 2012). This report received a great deal of media coverage, with nine newspaper stories from five different newspapers providing coverage of the findings of the report in 2012. The bulk of these were published in February. These included three in national newspapers: two from The Australian, with headlines suggesting: 'Lessons from Asia show the way forward for our schools' (Ferrari, 2012b), this being one of two 'page one' stories on the issue, and the second, 'Helping students learn key to better results' (Ferrari, 2012a). The Financial Review, the other national newspaper, also covered the release of the report suggesting: 'Asian education goes to top of the class' (Walker, 2012). The two other reports were in The Age, 'A class above' (Harrison, 2012a) and the Sydney Morning Herald, 'Shanghai surprise reveals a great learning culture' (Harrison, 2012b). The report also resurfaced in the media in September in the Sydney Morning Herald (Browne, 2012) and December of 2012 in The Age (Tovey \& McNeilage, 2012c), the Sydney Morning Herald (Tovey \& McNeilage, 2012b), and the Canberra Times (Tovey \& McNeilage, 2012a). Bourdieu (1996) calls this phenomenon where newspapers write stories first covered in other media outlets, 'circular circulation'. The article in the Canberra Times was the second 'page one' story on the Grattan Institute report. All of these stories focused on 'lessons from Asia' and 'races to the top'. However, as one report suggested, 'Framing PISA as an academic race ignores that each country aims to teach a curriculum emphasising its unique industrial and developmental needs' (Loader \& Whatmore, 2012, p. 9).

In addressing the release of the Grattan Institute report, that in the context of Shanghai's 2009 PISA results precipitated a PISA shock in Australia, the Prime Minister of the day, Julia Gillard, expressed real concern that in the so-called Asian century, Australia was in danger of becoming the 'runt of the litter' in Asia. She was quoted in The Australian as saying: 
Four of the top five performing school systems in the world are in our region and they are getting better and better ... On average, kids at 15 in those nations are six months ahead of Australian kids at 15 and they are a year in front of the OECD mean ... If we are talking about today's children - tomorrow's workers - I want them to be workers in a high-skill, high-wage economy where we are still leading the world. I don't want them to be workers in an economy where we are kind of the runt of the litter in our region and we've slipped behind the standards and the high-skill, high-wage jobs are elsewhere in our region. (Franklin, 2012, p. 1)

An outcome was the government legislating for Australia to be back in the top 5 performing nations by 2025. There was also impact in England and the US (Sellar \& Lingard, 2013). Australia's PISA shock then was linked to Australia's geo-political and economic positioning in relation to the economic rise of Asia and particularly that of China. The Henry Review about Australia and Asia, released around this time, also noted that Asian schooling systems were outperforming Australia.

Nations that experience shock as a result of their comparative PISA scores often respond very seriously in political and policy terms with the media playing an important role here, and at times subsequently react with significant education reforms. For example, Japan implemented a huge range of changes to their schooling, including the inclusion of a specific application of knowledge component in the national curriculum and the inclusion of an application of knowledge set of questions in the national tests after the 2003 PISA shock (Takayama, 2008, 2010). Germany's PISA shock in 2001 and the serious policy responses to it gave legitimacy to PISA as a significant international measure of systemic school performance. The important point to note here is how these responses really legitimated the national policy significance of PISA from the outset. PISA performance and media coverage of that performance now help to create 'widespread recognition of the need for change to take place' (Santiago, Tremblay, Basri, \& Arnal, 2008, p. 335). Indeed, PISA is designed to unsettle perceptions and create a sense of crisis amongst national policy makers, politicians 
and the broader public. Given this purpose of PISA and its effects, PISA data might then be regarded as a form of 'catalyst data' (Lingard \& Sellar, 2013).

Figure 5: Aggregated percentages of newspaper articles, by month 2000-2014 ( $n=173)$

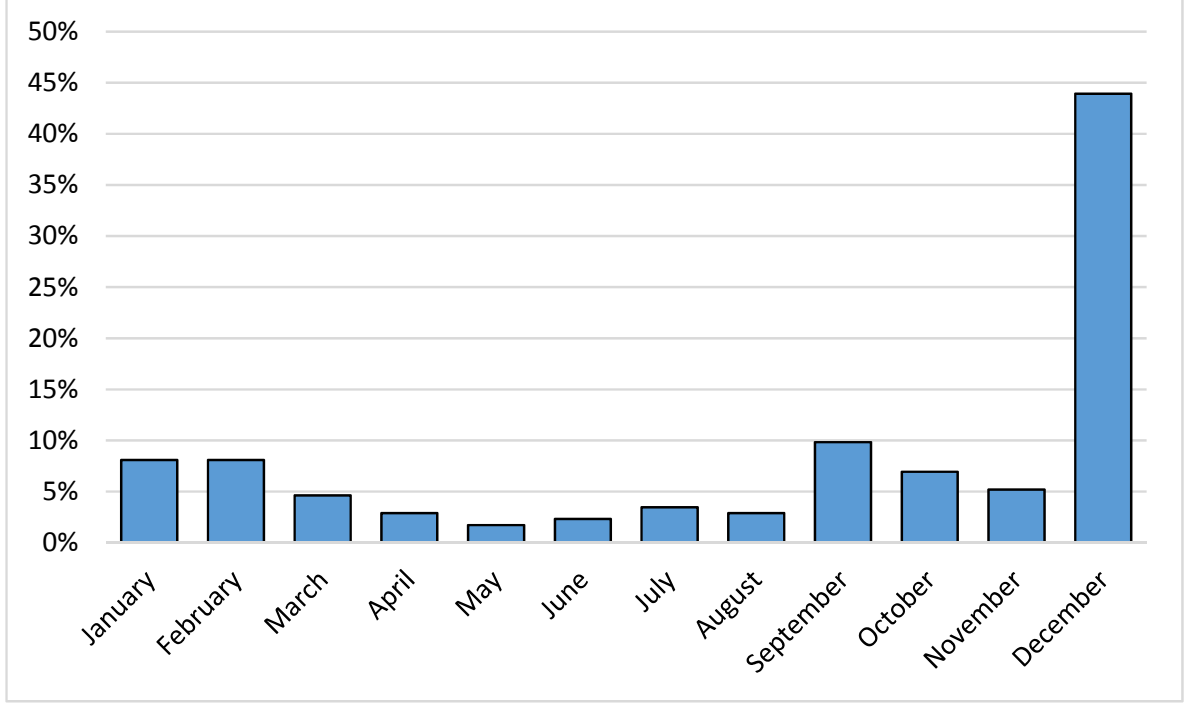

Media coverage was also concentrated in the December calendar month, the month in which the first PISA data analyses are released. This month generated approximately four and a half times more articles, across all newspapers and years, than September, which had the next largest number of articles (see Figure 5). This finding is consistent with those of other studies (Dixon et al., 2013; Elstad, 2012), which also found media attention spiked in December. This is understandable given the first PISA report is released by the OECD annually at this time. This has policy effects with the emphasis on quality of performance (counts and comparison in our terms). Detailed secondary analyses of PISA data are conducted subsequently and such analyses are usually released to the media in the following year to that when the initial results are made public. These very helpful and informative analyses receive much less media coverage than that achieved by the initial release of comparative national performance, but are probably more useful in policy terms. 


\section{Framing media coverage}

As noted earlier, three media frames were identified in media coverage of Australia's performance on PISA: what we have classified as counts and comparisons, criticisms, and contexts. These frames are briefly outlined below; however, this paper only focuses on the counts and comparisons frame. Most of the coverage (40 per cent) was concerned with the first frame, counts and comparisons, which analysed PISA data to provide counts that acted as 'evidence' that was then used to comparatively position Australia against other countries that do better, with particular emphasis on Finland and also Shanghai after the 2009 PISA. Here, in PISA terms, the focus was on quality rather than equity. The quality focus continues in the second frame, which identified a range of criticisms (28 per cent) of Australian governments and their policies, education systems including schools and universities, and groups such as teachers and teacher unions. The final frame centred on contextual issues (32 per cent), problematizing Australia's present and future positioning in the global context. These contextual issues predominantly focus on equity. These analyses are situated within considerations of the role of PISA and national testing and media constructs of school system performance in the Australian education policy landscape.

The different newspaper corporations did not report on the frames to the same degree. Figure 6 shows the Seven West Media newspaper reported on each of the themes somewhat equally, but also had the lowest volume of articles on the topic. News Corp Australia tended toward providing counts and comparisons that focused on discourses of quality in the bulk of their reportage, which was significantly higher than for Fairfax Media. Both News Corp Australia and Fairfax Media were relatively similar in terms of framing coverage based on criticisms of teachers and unions, schools, governments and education policies. However, Fairfax Media provided a deeper analysis of contextual factors associated with Australia's performance on PISA with some focus on equity. 
Figure 6: Prevalence of frames - aggregated number of articles by corporate ownership $2000-2014(n=302)$

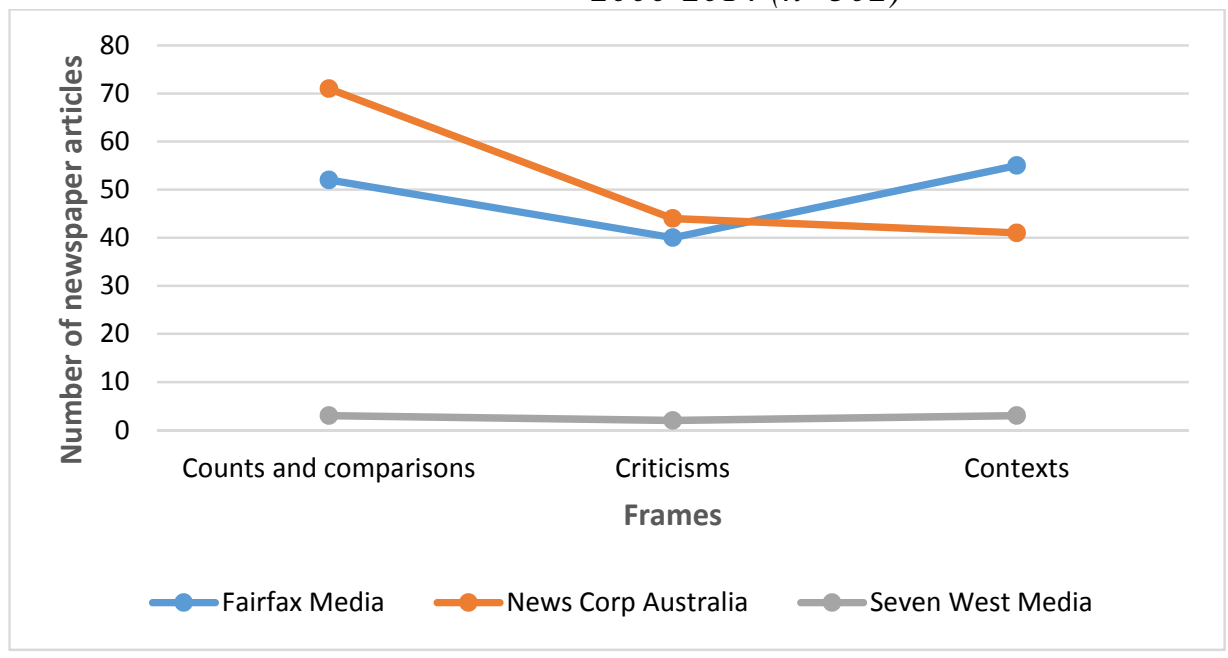

Based on the disaggregation of frames, the Sydney Morning Herald, the Canberra Times, and The Age, all Fairfax Media newspapers, tended to report Australia's performance on PISA more evenly across counts and comparisons, criticisms, and contexts. Their reportage on the equity frames represents around 40 per cent of articles. This is quite different when compared with the News Corp Australia newspapers that have a greater degree of variance in their reportage, with a range of approximately $18-28$ per cent. Similarly, reportage using the counts and comparisons frames averaged around 50 per cent in the News Corp Australia newspapers, compared with approximately 35 per cent for the Fairfax Media newspapers.

\section{Counts and comparisons}

PISA has taken on greater political and policy salience since its inception in 2000 within participating nations. This is linked to comparison as a new mode of educational governance, both globally and nationally (Nóvoa \& Yariv-Mashal, 2003). In many nations, including Australia, national testing has been created as a complement to PISA. Indeed, the OECD encourages the articulation of international and national large-scale assessments. Nations, and 
schooling systems, are anxious to be seen as performing well and continually improving on PISA. Nations want to benchmark their performance against others globally. Nations often utilise PISA results as a mode of 'externalisation' (Schriewer, 1990; Steiner-Khamsi and Waldow, 2012), whereby such results are used, not to learn from, but as legitimation for reforms a government wishes to pursue. We would add that media constructions of national performance on PISA comparatively and over time are important factors in the national responses to PISA performance.

The framing of Australia's performance using counts and comparisons was the most frequently selected and salient aspect of PISA testing in the Australian press. Here, similar to media coverage in other countries (Dixon et al., 2013; Pons, 2011), the focus was often on the negative aspects of Australia's performance. Australia's performance was often reported using a rank position in relation to all other participating countries. This ranking used the mean scores of all countries to generate these league tables. Figure 7 outlines Australia's rank, compared with other participating OECD and non-OECD countries participating in PISA, as identified in the OECD publications.

Figure 7: Australia's position compared with participating nations on mean scores 20002012

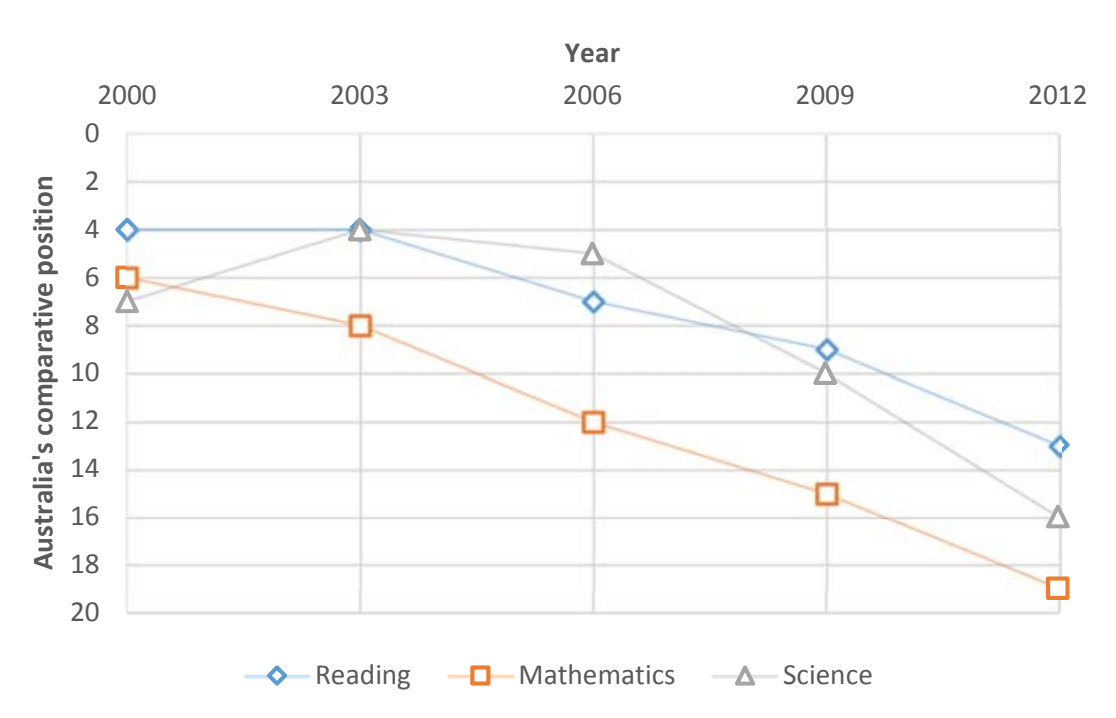


In the first two PISA tests, 2000 and 2003, Australia was placed in the top 8, compared with other participating countries, in reading, mathematics and science literacy. This prompted some reportage, (only 7 per cent of the total articles in this fame) that highlighted Australia's success. Coverage included this page-one story in the Sydney Morning Herald that stated Australian students 'have ranked in the top rung of a prestigious international scorecard' (Doherty, 2004, p. 1). This one, again in The Australian, suggested 'Australian students are among the best in the world at reading, maths and science' (Buckingham, 2004, p. 3); and this headline in the Canberra Times, 'Australia's education system gets full marks' (O'Connor, 2004, p. 11). Each of these examples, while highlighting elements of success in Australia's education system, does this by way of comparison with other countries. For example,

... only Finland had a significantly higher reading level. Only four countries in the PISA study were significantly better at mathematics - Hong Kong/China, Finland, South Korea and the Netherlands. And in scientific literacy, Australia ranked behind Finland, Japan, Hong Kong/China and South Korea and came just after these countries on problem solving. (Doherty, 2004, p. 1)

However, similar to the findings of other media studies (cf Dixon et al., 2013), when Australia's placement in the rank started declining across all three literacies, particularly in 2006 in mathematics, the press coverage increased and the tone became more negative. In particular, the focus of new reports was to provide evidence (49 per cent) that substantiated the media claims ( 31 per cent), usually about failing educational systems and poor national and global performance. For example, the lead paragraph in this page-one story in The Australian stated, 'Australia's top students are failing to keep pace with their international peers, with the latest OECD tests of high school pupils showing a drop in reading and maths skills' (Ferrari, 2007, p. 1). Similarly, this story in The Australian selected the same salient points, suggesting 'Australian teenagers are falling behind the rest of the world in school' 
(Ferrari, 2010, p. 2).

When framing counts and comparisons, the press frequently utlilised mean scores to rank participating countries as a mode of evidence regarding performance. In reading, Australia went from a mean score of 528 in 2000 to 512 in 2012, a drop of seven points, with the same drop of seven points in science literacy, from 528 in 2000 to 512 in 2012 . The worst change was in mathematics literacy where the country fell 29 points from a mean score of 533 in 2000 to 504 in 2012. This enabled dramatisation-style media coverage as a downward trend provided greater opportunity for sensationalism. For example, using mean scores and country ranks, Australia's performance in mathematics shows a downward trend, with a significant decline starting in 2003, and out of the top 10 by 2006 (see Figure 7). Additionally, as Dixon et al. (2013) suggest, negative reportage of a nation's global rank in PISA 'will have a strong negative effect on public opinion of a country's education policies' and conversely, 'the intensity and tenor of the press coverage will influence the political response' (p. 486).

By 2012, Australia was placed at the lower end of the top 20 for all three literacies (see Figure 7). Like Gorur and $\mathrm{Wu}$ (2015), we would suggest that discussions about a country's performance, based solely on mean scores and averages, are flawed, and we need to identify and use different 'geographical units' such as analysis based on test 'item content and by test completion' (Gorur \& Wu, 2015, p. 647) or disaggregated performance by state jurisdiction.

To illustrate the media focus on the negative and scandalous elements of a country's PISA performance, we provide the following example. While only 43 nations participated in the 2000 PISA, the number of participating countries has grown substantially since that time with 65 nations participating in 2012, with a further 40 per cent increase in participation rates in 2015 (see Table 2). Many of the additional countries are East Asian with Confucian 
traditions. Four countries in the top 5 rank in 2009 were Australia's East Asian neighbours, which it can be argued contributed to Australia's own PISA shock (Sellar \& Lingard, 2013). These increases in participating countries are rarely acknowledged in the press when discussing Australia's position in global rankings (cf Chilcott, 2010). This is a fundamental piece of information, as simple mathematics would suggest that ranks are more likely to change and decrease when the number of participants changes.

Table 2: Number of participating countries - OECD and non-OECD (2000-2012)

\begin{tabular}{|l|r|r|r|r|r|r|}
\hline Year & 2000 & 2003 & 2006 & 2009 & 2012 & 2015 \\
\hline Number & 43 & 41 & 58 & 74 & 65 & 71 \\
\hline
\end{tabular}

To illustrate our perspective on this, we conducted a subsequent analysis of Australia's PISA rank using only participating countries that were represented in all five test years. That is, only 32 countries $^{1}$ participated in PISA each year with data being available across the three literacies. This excluded the US as there was a printing error on the 2006 PISA test and the UK as their responses rates were too low in PISA 2000. Our analysis illustrates the arbitrary nature of using mean scores to rank countries and not taking into account the increases in numbers of countries participating over the years. We outline a few of these data below.

As Figure 8 demonstrates, in each of the literacies, Australia is ranked higher in 2009 and 2012 when analysed against the 32 countries, than when compared with the participating

\footnotetext{
${ }^{1}$ OECD member countries included Denmark, Finland, France, Germany, Greece, Hungary, Iceland, Ireland, Italy, Japan, Korea, Luxembourg, Mexico, New Zealand, Norway, Poland, Portugal, Spain, Sweden, and Switzerland. Non-OECD member countries included Hong Kong-China, Indonesia, Latvia, Liechtenstein, Russian Federation, and Thailand.
} 
countries of a particular year, making the changes in position less dramatic. For example, in mathematics, Australia is placed $12^{\text {th }}$ rather than $19^{\text {th }}$; in reading, $9^{\text {th }}$ rather than $13^{\text {th }}$; and in science, $10^{\text {th }}$ rather than $16^{\text {th }}$. While we acknowledge that our analysis is also somewhat arbitrary, our comparisons like those of the newspapers were conducted longitudinally across independent data sets (year of test). However, the difference was that the number of participating countries was consistent, thereby eliminating this variance and producing a different result in the ranking, where Australia's performance on PISA declined less significantly.

Figure 8: Australia's position in literacies based on 32 countries that participated in PISA across all years (2000-2012)

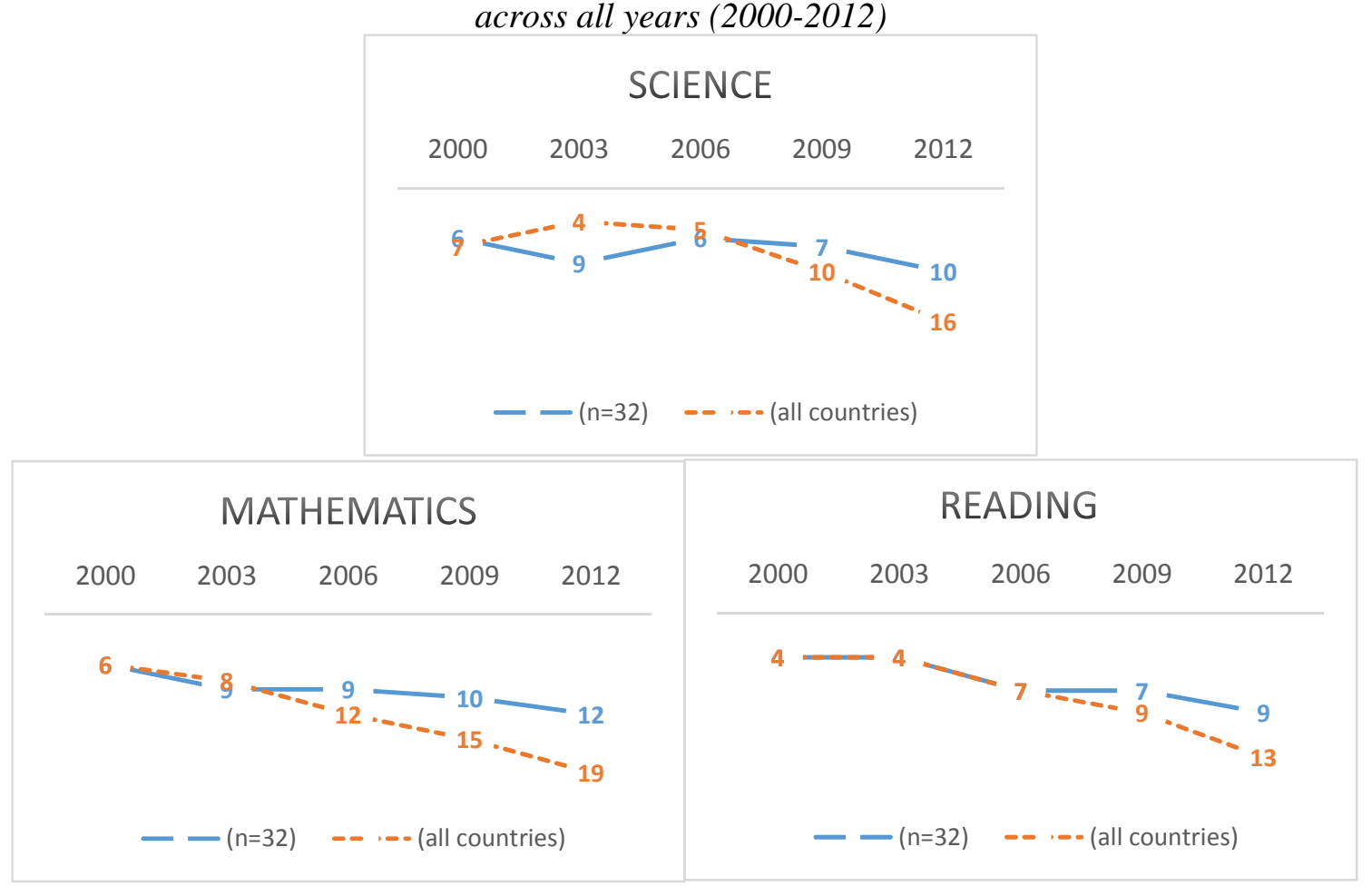

Within the processes of externalisation, 'reference societies' were also used to gauge and evaluate Australia's performance (Steiner-Khamsi, 2003). Initially, most references in newspapers constituted Finland (15 per cent) as a reference society for Australia's education system. Later, this was reconstituted with Asian schooling systems (30 per cent) being referenced as a panacea for Australia's PISA declining performance. Similarly, research by 
Waldow et al. (2014) found that up until 2007, high achieving Asian countries were not part of the Australian media's discussion on PISA in any detailed way. Interestingly, there is a different emphasis for each of these frames, that is, commentary relating to reference societies is supported through a focus on quality, while the framing on inequality uses the equity measure.

First, the relentless comparisons of Australia's PISA performance against that of other countries, again focusing on the 'negativity phenomenon' (Dixon et al., 2013), was frequently used to provide a basis for Australia's declining performance, but also to highlight the success of other nations. For example, this from the Sydney Morning Herald:

The School Education Minister, Peter Garrett, said that despite having one of the best education systems in the world, Australia lagged behind other countries - in particular in Asia. "This is not acceptable in a country as wealthy and well-resourced as Australia". (Rosenberg, 2012, p. 3)

And this from an opinion piece in The Australian:

While Australian education is riven with factions where pedagogic philosophy, arguments over teacher training, testing, NAPLAN, teacher pay, unions and Gonski fuel debate, China is outstripping Australia through two things: quality teaching and a culture of success related to hard work. (Bantick, 2012, p. 19)

When analysing the frequency in which a country was identified in media coverage, across all frames and within the combined data set (2000-2014), Finland and South Korea are similarly placed, followed by Shanghai and Hong Kong, then Singapore (see Figure 9). Except for Finland, all other countries in the top 5 on the 2009 and 2012 PISA are Asian. Each of these nations is significantly different from Australia in socio-cultural and sociopolitical terms, but they are still identified as reference societies for Australian educational reforms (Steiner-Khamsi, 2003; Sellar \& Lingard, 2013). Subsequently, a nation's referential position is no longer conditioned and legitimated by similarities with a society and a 
schooling system, but on the basis of their placement in the global rankings on PISA (cf Lingard, 2011; Sellar \& Lingard, 2013; Waldow et al., 2014). This basis for referencing other systems has replaced those based on history and cultural connections.

Figure 9: Distribution of references to other countries within news reports $(n=573)$

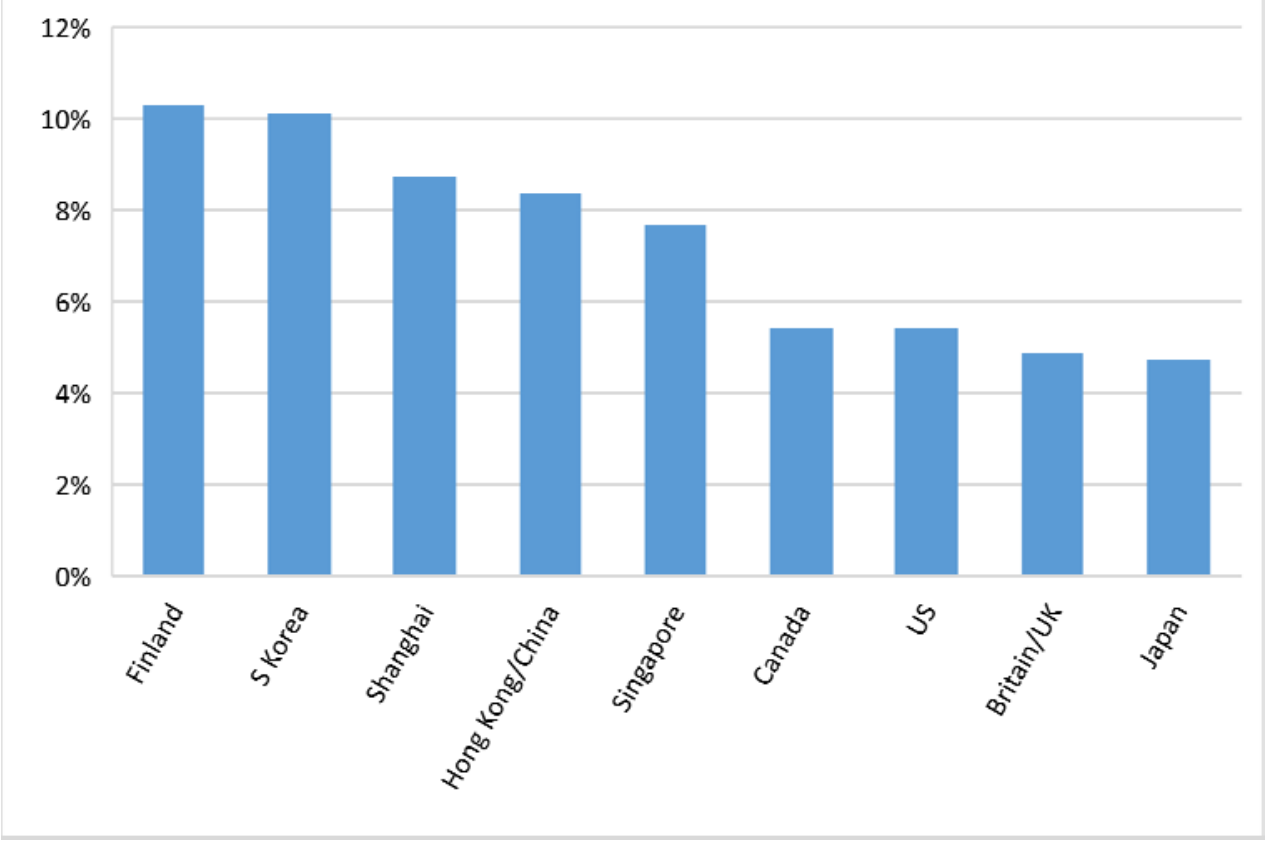

Media constructions also emphasise policy, rather than structural inequality explanations of national performance. While the Australian press did not stop referencing Finland, coverage also included Asian nations, especially Shanghai after 2009. The Australian reported, 'Shanghai, which joined the international testing movement in 2009 and ousted Finland from the top spot it had occupied for almost 10 years' (Ferrari, 2012a, p. 17), with the Sydney Morning Herald adding, 'Australian policy makers could learn much from China' (Harrison, 2012b, p. 13). Despite major cultural, demographic and political differences between Finland and Australian, and Shanghai and Australia, this did not prevent media constructions of Shanghai as a suitable reference system for Australian schooling. 


\section{Conclusion}

The media constructions of Australia's PISA performance over time, which we have documented and analysed, have the effect, discursively at least, of constituting an Australian schooling system, despite schooling being the Constitutional responsibility of the states and territories. The media speak of Australia's performance more than they speak of say New South Wales' performance or Western Australia's performance. This approach hides quite large disparities in performance across the various state schooling systems in Australia. Yet Australia, unlike the US for example, oversamples on PISA so that the results can be disaggregated to school system levels. The media rarely acknowledge this. On the most recent PISA analyses for 2012 PISA, Western Australia and the Australia Capital Territory did very well, while the Northern Territory and Tasmania performed comparatively poorly. This went largely unreported and what we saw instead was the media's fixation on national average scores and international comparisons within league tables.

Our analyses have also demonstrated that, league tables that 'count' school performance and visual representations that 'compare' performance produced by the OECD in respect of PISA, facilitate these media representations of school performance and play to the logics of practice of journalism and the journalistic field. Secondly, we have shown how media coverage of Australia's PISA performance has increased over time, paralleling the enhanced role of the OECD's education work in both the global and national governance of schooling. The introduction of national testing in Australia in 2008 also appeared to augment the extent of media coverage of PISA test performance. Thirdly, we have demonstrated how the media framed PISA stories around the categories of counts and comparisons, criticisms, and contexts, with our focus on counts and comparisons. Think Tank usage of publicly available PISA data also has real media effects, as we have demonstrated with our analysis of the political and policy impact of the Grattan Institute's report on Shanghai's performance on 
the 2009 PISA. This paper has demonstrated the constitutive role played by the media in respect of Australia's changing PISA performance over time and also suggested this constitutive role has policy effects.

\section{Acknowledgement}

This work was supported by the Australian Research Council (ARC) Discovery Grant: Schooling the nation in an age of globalization (DP1094850).

\section{References}

Afonso, N., \& Costa, E. (2009). Use and circulation of OECD's 'Programme for International Student Assessment' (PISA) in Portugal. Retrieved from http://knowandpol.eu/IMG/pdf/o31.pisa.portugal.pdf

Alterman, E. (2003). What liberal media? The truth about bias and the news. New York: Basic Books.

Auld, E. and Morris, P. (2016) PISA, policy and persuasion: translating complex conditions into education 'best practice'. Comparative Education. 52 (2), 200-229.

Bajomi, I., Berényi, E., Neumann, E., \& Vida, J. (2009). The reception of PISA in Hungary. Retrieved from http://knowandpol.eu/IMG/pdf/o31.pisa.hungary.pdf

Bantick, C. (2012, November 3). Chinese school system offers the West a lesson in educational achievement. The Australian, p. 19.

Baroutsis, A. (2016). Media accounts of school performance: Reinforcing dominant practices of accountability. Journal of Education Policy, 31(5), 567-582.

Birks, J. (2010). The democratic role of campaign journalism. Journalism Practice, 4(2), 208-223.

Blackmore, J., \& Thorpe, S. (2003). Media/ting change: The print media's role in mediating education policy in a period of radical reform in Victoria, Australia. Journal of Education Policy, 18(6), 577-595.

Bourdieu, P. (1996) On television. New York: The New Press.

Boyatzis, R. E. (1998). Transforming qualitative information: Thematic analysis and code development. Thousand Oaks, CA: Sage.

Braun, V., \& Clarke, V. (2006). Using thematic analysis in psychology. Qualitative Research in Psychology, 3(2), 77-101. 
Browne, R. (2012, September 5). World rankings a lesson in valuing role of teachers, Sydney Morning Herald, p. 5.

Buckingham, J. (2004, December 8). Aussies get high marks in world test. The Australian, p. 3.

Burgess, A. (2010). Media risk campaigning in the UK: From mobile phones to 'Baby P'. Journal of Risk Research, 13(1), 59-72.

Chilcott, T. (2010, December 8). Pupil rankings improve - Global assessment has state on better national footing. The Courier Mail, p. 9.

Cunningham, S. (2010). Policy. In S. Cunningham \& G. Turner (Eds.), The media and communications in Australia (3 ed., pp. 31-48). Crows Nest: Allen \& Unwin.

Dixon, R., Arndt, C., Mullers, M., Vakkuri, J., Engblom-Pelkkala, K., \& Hood, C. (2013). A level for improvement or a magnet for blame? Press and political responses to international educational rankings in four EU countries. Public Administration, 91(2), 484-505.

Doherty, L. (2004, December 8). Our students world class, but maths trips girls. Sydney Morning Herald, p. 1.

Elstad, E. (2012). PISA debates and blame management among the Norwegian educational authorities: Press coverage and debate intensity in the newspapers. Problems of Education in the 21st century, 48, 10-22.

Entman, R. M. (1993). Framing: Toward clarification of a fractured paradigm. Journal of Communication, 43(4), 51-58.

Entman, R. M. (2004). Projections of power: Framing news, public opinion, and U.S. foreign policy. Chicago: University of Chicago Press.

Ferrari, J. (2007, December 5). Our brightest students falling behind the world The Australian, p. 1.

Ferrari, J. (2010, December 8). Australian students fall behind. The Australian, p. 2.

Ferrari, J. (2012a, February 18). Helping students learn key to better results. The Australian, p. 17.

Ferrari, J. (2012b, February 17). Lessons from Asia show way forward for schools The Australian, p. 1.

Figazzolo, L. (2009). Testing, ranking, reforming: Impact of PISA 2006 on the education policy debate. Brussels: Education International. 
Fladmoe, A. (2011). Education in the news and in the mind: PISA, news media and public opinion in Norway, Sweden and Finland. Nordicom Review, 32(2), 99-116.

Franklin, M. (2012, January 24). We risk losing education race, PM warns The Australian, p. 1.

Gorur, R., \& Wu, M. (2015). Leaning too far? PISA, policy and Australia's 'top five' ambitions. Discourse: Studies in the Cultural Politics of Education, 36(5), 647-664.

Grek, S. (2008). PISA in the British media: Learning tower or robust testing tool? Retrieved from http://www.ces.ed.ac.uk/PDF\%20Files/Brief045.pdf

Grek, S. (2009). Governing by numbers: The PISA 'effect' in Europe. Journal of Education Policy, 24(1), 23-37.

Grek, S., Lawn, M., \& Ozga, J. (2009). Study on the use and circulation of PISA at the national Level: Scotland. Retrieved from http://www.ces.ed.ac.uk/PDF\%20Files/K\%2BPWP12.pdf

Gür, B. S., Çelik, Z., \& Özoğlu, M. (2012). Policy options for Turkey: A critique of the interpretation and utilization of PISA results in Turkey. Journal of Education Policy, 27(1), 1-21.

Harrison, D. (2012a, February 17). A class above. The Age, p. 11.

Harrison, D. (2012b, February 20). Shanghai surprise reveals a great learning culture. Sydney Morning Herald, p. 13.

Henry, M., Lingard, B., Rizvi, F., \& Taylor, S. (2001). The OECD, globalisation and education policy. Oxford: Emerald Group Publishing Limited.

Jensen, B. (2012). Catching up: Learning from the best school systems in East Asia. Retrieved from http:/grattan.edu.au/wpcontent/uploads/2014/04/129_report_learning_from_the_best_main.pdf

Josephi, B., \& Richards, I. (2012). The Australian journalist in the 21 st century. In D. H. Weaver \& L. Willnat (Eds.), The global journalist in the 21st century (pp. 115-125). New York: Routledge.

Kamens, D. H. (2013). Globalization and the emergence of an audit culture: PISA and the search for 'best practices' and magic bullets. In H.-D. Meyer \& A. Benavot (Eds.), PISA, power, and policy: The emergence of global educational governance (pp. 117140). Oxford: Symposium.

Lingard, B. (2011). Policy as numbers: Ac/counting for educational research. The Australian Educational Researcher, 38(4), 355-382. 
Lingard, B., \& Rawolle, S. (2004). Mediatizing educational policy: The journalistic field, science policy, and cross-field effects. Journal of Education Policy, 19(3), 361-380.

Lingard, B., \& Sellar, S. (2013). 'Catalyst data': Perverse systemic effects of audit and accountability in Australian schooling. Journal of Education Policy, 28(5), 634-656.

Loader, D., \& Whatmore, S. (2012, October 15). Why it's time for a class revolt. The Age, p. 9.

Macnamara, J. R. (2005). Media content analysis: Its uses, benefits and best practice methodology. Asia Pacific Public Relations Journal, 6(1), 1-34.

Martens, K., \& Niemann, D. (2013). When do numbers count? The differential impact of the PISA rating and ranking on education policy in Germany and the US. German Politics, 1-19. doi:10.1080/09644008.2013.794455

Matthes, J. (2009) What's in a frame? A content analysis of media framing studies in the world's leading communication journals, 1990-2005. Journalism \& Mass Communication Quarterly, 86 (2), 349-367.

McCombs, M., \& Shaw, D. L. (2007). The agenda-setting function of mass media. In O. Boyd-Barrett \& C. Newbold (Eds.), Approaches to media: A reader (pp. 153-163). London: Hodder Arnold.

McKnight, D. (2010). Rupert Murdoch's News Corporation: A media institution with a mission. Historical Journal of Film, Radio and Television, 30(3), 303-316. Medvetz, T. (2012) Murky power: 'Think tanks' as boundary organisations. Research in the Sociology of Organizations. 34, 113-133.

Mons, N., \& Pons, X. (2009). The reception of PISA in France: Knowledge and regulation of the educational system. Retrieved from http://knowandpol.eu/IMG/pdf/o31.pisa.france.pdf

Nóvoa, A., \& Yariv-Mashal, T. (2003). Comparative research in education: A mode of governance or a historical journey? Comparative Education, 39(4), 423-438.

O'Connor, C. (2004, December 13). Australia's education system gets full marks. The Canberra Times, p. 11.

Örnebring, H., \& Jönsson, A. M. (2004). Tabloid journalism and the public sphere: A historical perspective on tabloid journalism. Journalism Studies, 5(3), 283-295.

Paletz, D. L., \& Entman, R. M. (1981). Media power politics. New York: The Free Press. 
Papandrea, F., \& Tiffen, R. (2011). Media concentration in Australia. Retrieved from http://internationalmedia.pbworks.com/w/file/46422518/Draft\%20Australian\%20Cha pter\%20\%28June2011_Rev\%29.docx

Patterson, T. E. (1996). Bad news, bad governance. The Annals of the American Academy of Political and Social Science, 546(Jul), 97-108.

Pons, X. (2011). What do we really learn from PISA? The sociology of its reception in three European countries (2001-2008). European Journal of Education, 46(4), 540-548.

Rosenberg, J. (2012, January 24). NAPLAN results show top students' standards drop. Sydney Morning Herald, p. 3.

Rostas, Z., Kosa, I., Bodo, J., Kiss, A., \& Fejes, I. (2009). Use and circulation of PISA in a Romanian context. Retrieved from http://knowandpol.eu/IMG/pdf/o31.pisa.romania2.pdf

Santiago, P., Tremblay, K., Basri, E., \& Arnal, E. (2008). Tertiary education for the knowledge society: Special features: governance, funding, quality (Vol. 1). Paris: OECD.

Schriewer, J. (1990). The method of comparison and the need for externalization: Methodological criteria and sociological concepts. In J. Schriewer \& B. Holmes (Eds.), Theories and methods in comparative education (pp. 25-83). Frankfurt: Peter Lang.

Sellar, S., \& Lingard, B. (2013). Looking East: Shanghai, PISA 2009 and the reconstitution of reference societies in the global education policy field. Comparative Education, 49(4), 464-485.

Sellar, S., \& Lingard, B. (2014). The OECD and the expansion of PISA: New global modes of governance in education. British Educational Research Journal, 40(6), 917-936.

Sellar, S., \& Lingard, B. (2015). New literacisation, curricular isomorphism and the OECD's PISA. In M. Hamilton, B. Maddox, \& C. Addey (Eds.), Literacy as numbers: Researching the politics and practices of international literacy assessment (pp. 1734). Cambridge: Cambridge University Press.

Stack, M. (2006). Testing, testing, read all about it: Canadian press coverage of the PISA results. Canadian Journal of Education, 29(1), 49-69.

Stack, M. (2007). Representing school success and failure: Media coverage of international tests. Policy Futures in Education, 5(1), 100-110. 
Steiner-Khamsi, G. (2003). The politics of league tables. Journal of Social Science Education, 1. doi:10.2390/jsse-v2-i1-470

Steiner-Khamsi, G. and Waldow, F. (Eds) (2012) Policy Borrowing and Lending in Education. London: Routledge.

Takayama, K. (2008). The politics of international league tables: PISA in Japan's achievement crisis debate. Comparative Education, 44(4), 387-407.

Takayama, K. (2010). Politics of externalization in reflexive times: Reinventing Japanese education reform discourses through 'Finnish PISA success'. Comparative Education Review, 54(1), 51-75.

Takayama, K., Waldow, F., \& Sung, Y.-K. (2013). Finland has it all? Examining the media accentuation of 'Finnish Education' in Australia, Germany and South Korea. Research in Comparative and International Education, 8(3), 307-325.

The Australian. (2004, December 8). How Australia can go to the top of the class. The Australian, p. 16.

Tovey, J., \& McNeilage, A. (2012a, December 15). Global race to top of the class. The Canberra Times, p. 1.

Tovey, J., \& McNeilage, A. (2012b, December 15). The great race to the top of the class. Sydney Morning Herals, p. 6.

Tovey, J., \& McNeilage, A. (2012c, December 15). Learning lessons from the countries at the top. The Age, p. 17.

Waldow, F., Takayama, K., \& Sung, Y.-K. (2014). Rethinking the pattern of external policy referencing: Media discourses over the "Asian Tigers" PISA success in Australia, Germany and South Korea. Comparative Education. doi:10.1080/03050068.2013.860704

Walker, T. (2012, February 18). Asian education goes to top of the class. Financial Review, p. 62 .

Wiseman, A. W. (2013). Policy responses to PISA in comparative perspective. In H.-D. Meyer \& A. Benavot (Eds.), PISA, power, and policy: The emergence of global educational governance (pp. 303-322). Oxford: Symposium.

$\mathrm{Wu}, \mathrm{M}$. (2010). Measurement, sampling, and equating errors in large-scale assessments. Educational Measurement: Issues and Practice, 29(4), 15-27. 
Yemini, M., \& Gordon, N. (2015). Media representations of national and international standardized testing in the Israeli education system. Discourse: Studies in the Cultural Politics of Education, 1-15. doi:10.1080/01596306.2015.1105786 